\title{
Greek and Arabic in Nessana
}

\author{
Rachel Stroumsa
}

\section{Introduction}

Greek, Latin, Arabic, Nabataean and Syriac - all of these languages are found among the Nessana documents, and to a greater or lesser extent, all of them have left their mark on the Nessana community. The relative importance of these languages, and the meaning of their presence in different types of documents, has been the source of many casual mentions since their discovery some eighty years ago, though not of any sustained debate. This paper will attempt to examine the role of Greek in the years covered by the papyri-from the early sixth century to the late seventh century - and in particular the interaction of Greek and Arabic in the community. ${ }^{1}$

An appropriate place to begin might be one of the least promising papyri in the Nessana collection: a fragmentary papyrus, relegated by the editor of the corpus, Casper Kraemer, to the tail end of the edition and lumped together with other "minor documents." P.Ness. 145 comes from the early seventh-century church archive, and is not only fragmentary, but also incomplete. The writer begins composing an official letter, apparently dealing with household provisions; but after seven lines - five of which are spent on salutations and courtesies - he becomes dissatisfied with his efforts. He then turns the papyrus over and begins writing a letter again, only to grow discouraged at the difficulty of the task, this time after only one line of salutation. Having given up on the actual letter as a task beyond him, the writer then turns the papyrus around by 90 degrees and practices writing only one sentence over and over again, on both

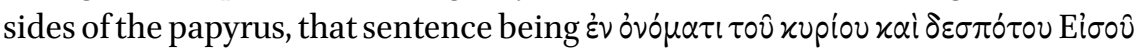

1 Compare the study on the relations between Arabic, Greek and Coptic in a corpus of papyri from early eighth-century Egypt (Richter, Language choice). On multilingualism in early Arab Egypt, see also el-Abbadi's article in this volume. For a general discussion of the papyri found in and near two churches in Nessana and a comparison with other multilingual dossiers found in Egypt, see also Sijpesteijn, Arabic-Greek. See also in this volume O'Sullivan's use of the same papyri from Nessana to reconstruct changes taking place in the economic administration after the Arab conquest.

(C) RACHEL STROUMSA, 2015 | DOI:10.1163/9789004284340_010

This is an open access chapter distributed under the terms of the prevailing CC-BY-NC License at the time of publication. 
Xpı different spellings of óvó $\mu \alpha \tau \iota$; he experiments with abbreviating Eiøov̂ Xpı

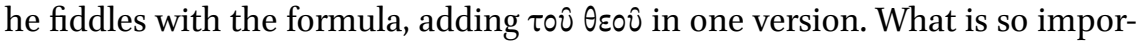
tant about this sentence that this man concentrates on it, even when other writing proves to be beyond him? Why would someone expend so much energy on one particular phrase, given that he cannot complete a simple request for more vinegar?

The standard interpretation of this document, exemplified in the first instance by the editor, Kraemer, is that the author is a "Hellenised" inhabitant of Nessana, and that his shaky knowledge of written Greek proves the deterioration of education in the township. ${ }^{3}$ This interpretation is in line with a more general trend, in which, by mapping out the interplay between various cultures and identities in the Near East, scholars often attempt to describe a socio-cultural reality by using linguistic evidence to yield a quantifiable result. The central, unfounded assumption is that the use of language allows us to determine ethnic, religious and cultural identities. This approach is problematic on two fronts, the abstract and the empirical; and a careful examination of Greek and its usage in the Nessana corpus will allow us to reach a different understanding both of this document and others.

On the theoretical level, reading language as a necessary and sufficient mark of identity is anachronistic at best, relying, explicitly or not, on nineteenthcentury notions of personal and group identity. ${ }^{4}$ While scholars often speak of the linguistic and cultural diversity of the region, there is still a tendency to presume homogeneity within an identity, to assume that a person's identity

2 The homogeneity of the writing and ink preclude any change in writers or the identification of the papyrus scrap as used for pen tests.

3 Kraemer, Excavation 319.

4 The assumption of a one-to-one correlation between linguistic habits and ethnic groupings stems from modern European notions of the nation-state and a Romantic understanding of identity as a mystical, stable construct, whose existence is untouched by changing historical and social situations. The roots of this identification of language and culture are found in the eighteenth century with Herder's prescription of one language per people, and obviously one language per person. This notion was then picked up by philologists and historians in the nineteenth and early twentieth centuries, who divided the world into distinct races or cultures, assuming that group identity within a 'society' or a 'culture' was homogenous and stable. Any particular group was understood to be unchanging through time and space, and all individuals within that group were expected to participate equally in all facets of that culture. The continuation of this mindset in modern scholarship has been criticised by, among others, Jones, The archaeology; Hall, Ethnic identity; and Amory, People and identity [2003]. 
is defined and discrete. Though the region as a whole is often described as a "mosaic" of languages and cultures, ${ }^{5}$ any particular individual is described as either "Greek" or "Semitic," either "Hellenised" or not. By assuming that identity has a monolithic nature, scholars are also prone to assuming that differing indicia can be used as positive and certain criteria for determining an identity. Thus we find scholars assuming that language is a straightforward indication of identity, ethnicity or religion, rather than seeing language as one element among many, used situationally in the construction of a fluid, shifting identity.

The deep-rooted assumptions underpinning such scholarly analyses have led to a view that cultural identity can be quantified: if every individual has a definite and definable identity, the cultural makeup of the population can be divided and counted. This approach stands at the base of the debate between the Hellenists and the Semiticists, who claim to distinguish the cultural makeup of the area, based in great part on linguistic usage. Both parties start from the same premise - that an answer is attainable, and that it will be one identity or the other. Thus both Fred Donner and Glen Bowersock see late antique Syria and Palestine as bifurcated into two communities, the Greek and the Semitic, and the argument between them focuses on where the boundaries defining these two distinct and discrete communities lie. ${ }^{6}$ Both sides of the modern debate accept as a given the existence of an unbridgeable gap between the Semitic-speaking population and the Greek-speaking population. Both sides take for granted that an individual would have had one genuine identity, and that the job of the scholar is to discern that identity, and then tally up the number of "true Greeks" and "true Arabs."

My argument here is that this view consists of a fundamental misconception, leading to a false dichotomy between "Greek" and "Arab" and to a misleading debate as to the identity of particular people. As mentioned before, the reliance on language as a marker of ethnic identity has been discredited, and it is particularly inappropriate for the world of late antique Palestine. On the empirical level, an examination of the papyrological testimony of Nessana, as well as other evidence from sixth- and seventh-century Palestine and Syria, will reveal that this approach is simply not borne out by the facts: linguistic, ethnic and religious boundaries do not coincide so neatly. ${ }^{7}$

5 See for instance, Cameron, The Mediterranean 185.

6 Bowersock, Hellenism esp. 72-77; Donner, The early 94.

7 Similarly, scholars used to distinguish native Egyptian, Coptic speakers from Greek speaking Hellenes based on the Egyptian papyrological material. For a more nuanced picture, see Papaconstantinou, Dioscore et la question; Fournet, Archive ou archives; Fournet, The multicultural environment; Boud'hors, Du copte; and to a certain extent already Wipszycka, Le 
If, then, language is not operative in distinguishing ethnic identity, we will be left questioning its use, since it is very clear that more than one language was in play in the community and that the choice of language was not random. The question to be examined thus becomes what roles did the different languages play: in what context and for what purposes were they used?

\section{Greek in Nessana}

Often the first characteristic to be commented upon, the Greek papyri contain what are frequently described as "barbarisms": many of the texts deviate substantially from standard Greek spelling, grammar and syntax. Kraemer, who does not shy away from value judgments, reads this as evidence of a significant decline in education: "the priest who wrote the text of 57 as well as the archdeacon author of 56 were both, as far as Greek was concerned, only semiliterate. In fact, the carelessness or ignorance of the scribe George is rather noteworthy." ${ }^{\prime}$ Kraemer describes a community where Greek used to be the primary language, whose inhabitants are still "Hellenised," but no longer have the education to express themselves in "acceptable" standard Greek. This account leaves us without an explanation for the insistence on writing in Greek, given the supposed massive decline in education. It also flies in the face of recent scholarship on the evolution of language, and in particular, the parallel changes in contemporary Latin in the western Empire. ${ }^{9}$ Compared to the Latin of Gregory of Tours, for instance, the Greek found in Nessana shows many of the same characteristics, suggesting that the problem is not an inability to write in "correct" Attic Greek but that we see here an alteration in progress. Kraemer's account of declining knowledge is also at odds with what we know of Greek learning elsewhere in Palestine: Cyril Mango has demonstrated the vitality of Greek culture in Palestine in the early eighth century, showing that this was "the most active centre of Greek culture" at the time. ${ }^{10}$ Altogether, then, on both theoretical and practical grounds, it appears that ignorance and slovenliness will not suffice as explanations for the idiosyncrasies of the papyri.

nationalisme. See also Vieros, Bilingual notaries for a discussion of the fluidity of bilingual Egyptian-Greek scribes in Egypt from the first century вСЕ to the first century CE.

$8 \quad$ Kraemer, Excavation 157.

9 Banniard, Viva Voce.

$10 \quad$ Mango, Greek culture 149. 


\section{Greek and Spoken Arabic}

If we try to set aside any preconceptions and examine the documents in terms of their functions, the Greek documents fall into two groups. Some documents reflect an idiomatic, easily spoken Greek. Many of these papyri, such as P.Ness. 38 and 82 , were evidently meant for personal use, and as such are little more than aides-mémoire or notations for personal archives.

Naturally, the fact that Nessanites were comfortable in Greek, both spoken and written, has no influence on whether they were also at ease in Arabic; and indeed, the evidence does point to a widespread use of Arabic as a vernacular. ${ }^{11}$ The most obvious instance of this infiltration of Arabic into the Greek text comes in the form of place names. Three places mentioned in the papyri include obvious Arabic elements: X $\alpha \varphi p \varepsilon \alpha[\ldots]$ in P.Ness. 54, X $\alpha \varphi \rho$ in P.Ness. 94,

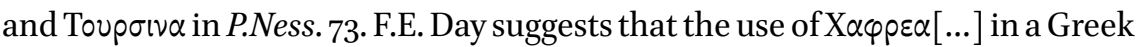
document implies that the writer "did not realise the native usage, and took kafr as a place name, omitting its relative word." "12 Yet the opposite conclusion may also be drawn, and as we shall see, it is more in keeping with the rest of the evidence-viz., that the writers knew full well that kafr was a village, that the place indicated was called Kafr $\mathrm{x}$, and that the missing remainder of the name would have supplied the full toponym. This is supported by the later reappearance of a place called Kafr in the post-conquest P.Ness. 94. Given the date of that manuscript, we can hardly assume the writers to be ignorant of the meaning of the word kafrin Arabic, and yet we still find it used as a place name. Clearly, then, it is rash to assume that this usage implies ignorance of Arabic convention. A similar instance appears in an order from the Muslim governor, dated to 683 , where Mt. Sinai is called Toupowv (73.7). Here again we have the identifier of a place $(t \bar{u} r)$ used as a portion of the proper name of a place, and thus according to Day's rationale, we ought to assume ignorance of Arabic; and yet the date and context of this document assure us of the writer's knowledge of Arabic. We may then read the use of Arabic place descriptions as evidence for knowledge of Arabic.

Even clearer proof of the widespread use of Arabic as a spoken language is furnished by the Arabic words used to describe plots of land. Altogether, fourteen fields are given proper names, in papyri ranging in dates from 512 (P.Ness. 16) to the late seventh century (P.Ness. 82). Thirteen of the names are indubitably Semitic in origin, and have a meaning in Arabic. Day suggests that

11 Contra Wasserstein, Why did Arabic succeed 261.

12 Quoted in Kraemer, Excavation 152. 
alegrad in P.Ness. 24.6 is simply al-ajrād, plural of jarad, field..$^{13}$ Two of the fields mentioned have a similar name-abiathalbon in P.Ness. 16, and abiathalba in P.Ness. 21, written 40 years later. These may refer to the same field or to two separate fields; in either case we might suggest that the name is a reflection of $a b$-thalaba, i.e. the possessor of foxes, or the field (inhabited by) foxes. Two fields are named after their master in P.Ness. 82- $\mu \alpha \lambda \alpha \lambda \varkappa \alpha v l$, i.e. māl al-kāni, property of the short man, and $\mu \alpha \lambda \zeta \eta \mu \alpha p \chi \varepsilon$, or māl dhi māriq, property of the deserter or the heretic. ${ }^{14}$ Another field is called $\beta \varepsilon p \alpha \varepsilon i v$, i.e. the two wells (P.Ness. 82.1). ${ }^{15}$ The use of Arabic words, and not just proper names, to identify sections of land, implies that Arabic served in daily life, particularly when discussing elements of agricultural life such as the fields. This use is paralleled in the papyri from Petra where we find over 100 Arabic toponymns and oikonyms embedded in otherwise Greek texts-and there, too, it can be assumed that Arabic was used in daily life especially in an agricultural context. ${ }^{16}$ Both in Petra and in Nessana the documents disposing of the fields and naming heirs were written in Greek, but the business of farming appears to have been conducted in Arabic.

\section{Greek and Written Arabic}

The difference between the use of Greek and Arabic, then, does not lie in who spoke which language, as we see that use of Greek does not preclude a deep familiarity with Arabic as a vernacular. The difference between the two manifests itself in the second category of Greek documents, those not meant for private but for public consumption. In these cases Greek is used to convey additional connotations of power and authority, serving as more than just a straightforward, limpid tool for conveying the spoken words. This aspect is particularly apparent in the post-conquest papyri, written well into Muslim rule, in contracts like P.Ness. 56 and government communications like P.Ness. 73 .

\footnotetext{
13 Kraemer, Excavation 79.

14 This could also be a transliteration of māl dhì märikh, i.e. property of the proud man.

15 In view of these readings, we might propose that the field Kraemer reads as Aıрє $\lambda \alpha$ be emended to الرجلة, i.e. al-rijla, the water-channel; this would allow us to transform it from a meaningless name (and one, moreover, that does not follow either a Semitic or a Greek form) to a meaningful description, consistent with other field names. 
Observations relating to the function of languages in Palestine under late Roman and Byzantine rule and Filasțīn under Umayyad rule are more often than not detached from each other, partly as a result of the disconnect between scholars of Late Antiquity and scholars of the early Muslim period. Since, then, pre-conquest documents are in Greek, and it is only through a closer analysis that we see the spoken Semitic dialects, Umayyad historians tend to speak of the "arabisation" of the Christian population, implying that until the latter half of the seventh century the population spoke Greek as a matter of course. The texts examined here suggest that this is only a partial truth; Christians in the Shām were indeed familiar with Greek, but even before the conquest it was used in situations where conveying power, status and culture were of importance.

The Nessana papyri show that a people who seem to have spoken a version of Arabic in daily life and nicknamed their fields in that language chose to resort to Greek when drawing up various contracts (P.Ness. 16 and 30, for instance), with the presumed intention of increasing the formality of the documents. This division of languages according to their connotations continues in the Nessana papyri after the Muslim conquest, when in fact we can see it even more clearly. P.Ness. 92, a record of accounts involving orders from Damascus and Egypt, represents the highest levels of Umayyad authority, including the governors of Egypt and Palestine and the caliph 'Abd al-Malik himself. Written at the very end of the seventh century - probably around 690 — the document is entirely Arabic in content; in fact, it is nothing but a memo internal to the Umayyad administration. All the names and titles mentioned are transliterated from Arabic (note in particular Amīr al-Mu'minīn, commander of the believers, as applied to the caliph); the institutions and administrative habits are all Arabic; the record deals with payment for the Muslim army. And yet, this detailed and formal text is composed entirely in Greek. Unlike the bilingual entagia from the same period, it does not even have a translation into Arabic appended to it.

That the Umayyad regime used Persian, Coptic and Greek for its accounts is well known; usually the phenomenon is explained as a result of the new regime, relatively poor in administrative structure, choosing to take over the intricate bureaucracy of the Byzantine and Persian empires wholesale, and maintaining the scribes who therefore continued to write in Greek. ${ }^{17}$ This situation held until the 69os, when Arabic gradually replaced all other languages.

17 See Sijpesteijn, The Arab conquest, for an argument in favour of Arab administrative tradition based on the Egyptian papyrological material; and O'Sullivan in this volume for the claim that the Nessana material similarly shows Arabic economic administrative sophistication. 
Yet if we examine not just the use of Greek from 636 to the time of the Abbasids, but look at these texts in the context of the preceding centuries, another possibility emerges; namely, that the continuities in the use of Greek reflect something other than a continued use of the same scribes. After the conquest, as before the conquest, the use of Greek among a population fluent in Arabic or Aramaic carries connotations of power and status. Thus although we find inscriptions in Semitic dialects, these tend to be private, not public. In the beginning of this chapter we saw how scholars often conclude from the use of Greek for written documents and inscriptions that the writers' cultural identity must have been Greek. Clearly, this assumption will not hold when we look at the Umayyad documents: their users and patrons could not possibly be said to be "Hellenised."

By this stage - well into Muslim rule in the 68os and 69os-Greek is no longer a koinē; it is neither the language of the empire nor the language of daily commerce. A common explanation is that Greek remained the language of the administrators. Bowersock has shown that the limited number of Arabic scribes is not a sufficient explanation. ${ }^{18}$ In addition, the entagia sent to Nessana from Gaza preserve a different story - one of two parallel systems of scribal notation and administration: the former, Greek-based and Byzantine in origin, supplemented by a new cadre of Arabic scribes. Thus, by the last quarter of the seventh century, there was a functioning Arabic administrative system, which did not supplant but merely enhanced the existing Greek system. This means that though commonsense would dictate that the new administrators were likely to be bilingual — and indeed that has often been the assumption - the administrative system itself did not require bilingualism, and in some sense may be said to have discouraged it; such a skill may have come in useful, but the system functioned without it.

It is worthwhile noting that the tendency to use a language other than Arabic for formal communication is not unprecedented, but in fact continues the practices of pre-Islamic Arabia and the Hauran. Before Islam, Arabic was not used in writing; instead the script of prestige in the locality was chosen.19 In a multilingual society, where people were often fluent in more than one dialect or language, the distinction between them becomes a matter of tone, conveying a message by the very choice of language. It is this sensibility that we see continued in the Greek papyri at Nessana. The so-called arabisation of Syria and Palestine is only in part then a process by which Arabic became

18 Bowersock, Hellenism 77.

19 Hoyland, Language and identity 184. 
the spoken language: to a certain degree a dialect of Arabic was already the colloquial language. More importantly, the transition from Greek to Arabic reflects the growing prestige of the new Muslim rulers. By the time of the Abbassids, there was no longer a need to use Greek to convey messages of power and status: Arabic represented a powerful enough rule. Only at that point was there no longer a need for public inscriptions in Greek, just as the coins then demonstrate an independent style and Arabic legends. ${ }^{20}$

\section{Parallels and Comparanda}

Further confirmation for this view of language as a tool of status and a symbol of imperial power is found in the few Latin papyri found in Nessana. Though none of the documentary papyri is in Latin, or indeed shows any significant knowledge of the language, the literary papyri include two singular exemplars: a Latin-Greek glossary of the vocabulary in the Aeneid, and fragments of books II-VI from a papyrus codex of the Aeneid. Both these papyri are notable for the abysmal quality of their Latin; indeed, the illiteracy of the glossary scribe is such that Casson and Hettich speak of "monstrosities," ${ }^{21}$ and describe the scribe-not unfairly — as merely copying the shapes of the strokes to the best of his ability, with no attempt to make sense of the letters. To give but a few examples from the glossary, Peget stands in for pigebit (749); Efello for refello (818); hortamuis for hortamur (445). This is not a question of making a mistake in the use of the subjunctive, or using the accusative case where we would expect a genitive. This is not a case of typical scribal error, or the mistaking of one word for another. What we see in these papyri is only the outward semblance of a language, comparable to the gibberish babbling of a child imitating adults. We may be tempted to put this down to a novice apprentice or to a phenomenally and singularly inept scribe, were it not for the fact that the papyrus shows signs of extensive revisions by another hand, just as ill-informed. The first scribe then passed on his efforts to be corrected by a superior, whose knowledge of Latin proves to be just as execrable.

The insistence of the sixth-century scribes on going far beyond the limits of their knowledge of Latin, and the continued use of such a poor text (as attested by the careful, if unsuccessful, attempt at emendation) is even more incomprehensible in view of the limited usefulness of Latin. Kraemer, following Casson

20 Shboul and Walmsley, Identity and self-image 287 .

21 Casson and Hettich, Excavations 11. 
and Hettich, suggests that the impetus is a Christian one, rooted in the view of Virgil as Christian avant la lettre. It is difficult to accept a religious reason for insisting on Virgil given that these texts are nearly unreadable; surely an appreciation of the subtle Christian interpretations of elements in the Aeneid would have been difficult, if not impossible, given this mutilated and often incomprehensible copy. A Christian explanation also seems unnecessarily restrictive, given the preponderance of pagan Hellenistic imagery elsewhere in the Christian communities of the region. ${ }^{22}$

As for practical reasons for a small school in the Negev to insist on Latin, these are also hard to countenance: Latin had already become a "complete anachronism" by the seventh century. ${ }^{23}$ It may be that what we see here is the well-known phenomenon of lag between centre and periphery: although by the time these papyri were written, at the end of the sixth century, Latin was no longer necessary or even important for administrative or cultural prestige in the imperial centres, this change in attitudes to the language had not yet reached Nessana. Thus the glossary and the Aeneid codex still reflect the situation in the late fifth and early sixth century, when Latin was the official language of law, the administration and the army, and knowledge of Latin was useful for aspiring bureaucrats and administrators. This remnant of an outdated outlook, which saw in Latin the mark of a man educated beyond the common run, would explain why such care was taken with the glossary in spite of the obvious limitations of both the primary scribe and the secondary scribe attempting to emend the former's mistakes. Latin still stands here as one of the trappings of imperial culture and power, just as it is still used in legends upon coins and in the legal texts taught at the university of Berytus, even when the language of instruction was firmly established as Greek. ${ }^{24}$

We see here a clear illustration that the prestige associated with a language is not diminished through spelling, grammatical and syntactical mistakes. On the contrary, the more incomprehensible a text is the more of an aura it gains. As a symbol of status - an attempt to lay claim to a heritage of power and prestige - the external appearance of a language, as expressed by an alphabet, is sufficient. This phenomenon is motivated by the same forces which create instances of pseudo-writing.

The popularity of Classical pagan cultural traditions such as Homeric stories and depictions of Pan and satyrs is amply demonstrated in the iconography of the Jerash bowls from the same period: Shboul and Walmsley, Identity and self-image 281 .

23 Cameron, The Mediterranean 310.

24 Geiger, How much Latin 41-42. 
In a sense, there is nothing new in this observation of a "division of labour" between the languages; as a rule, it is recognised that the Christian communities of Palestine in Late Antiquity spoke a Semitic dialect, and that Greek served as the primary language of worship and theology in the desert monasteries even among non-Greek speakers. ${ }^{25}$ So far, the scholarly discussion has focused mainly on speakers of what was known to contemporaries as siriste, or literally the Syrian language, and is conventionally labelled Christian Palestinian Aramaic (CPA), ${ }^{26}$ though the patterns are similar to those we have just seen.

A fine example of this Greek-Aramaic code-switching comes from Madaba. There a sixth-century Greek inscription describes a miraculous rainfall in Greek, but quotes the inhabitants' reaction to it in Aramaic-"goubba bagoubba," cistern for cistern. The inscription is seen as proving that the mass of the residents spoke Aramaic to the exclusion of Greek, in contrast to the writers and readers of the inscription. ${ }^{27}$ I would suggest that, seen in the context of other linguistic 'incongruities,' instances in which the language used does not seem to correspond to the language spoken, another interpretation suggests itself: that the shift in the text between Aramaic and Greek expresses a shift in the situation and medium, rather than in the identity of the users. When inscribing a formal document, the appropriate language is Greek; but when quoting a spoken exclamation, said in surprise at a miraculous downpour of rain, the appropriate vehicle is Aramaic. This is not bilingualism, but rather code-switching, the use of different languages for different purposes: Greek, Latin and Arabic are used as we would use different registers of the one language. This conclusion gains in plausibility when we look beyond Nessana and sixth-century provinces of Palestine and Arabia to Umayyad al-Shām, where we find several other instances of Greek used as a marker of power.

In Hammat Gader, the hot springs below Gadara (Umm Qays), a monumental and carefully cut Greek inscription informs us over nine lines that the bath

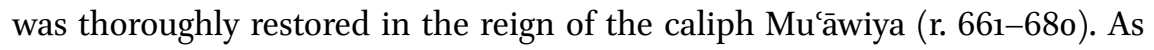
Fowden has shown, the stone maintains both the conventions and even the letterforms and general aesthetic of pre-Islamic inscriptions. ${ }^{28}$ The name and title of the caliph and the name of the local governor are carefully transliterated from the Arabic, while the governor's title is translated. It is perfectly clear that

\footnotetext{
25 Griffith, From Aramaic.

26 Millar, Ethnic identity especially p. 162 for a review of the term CPA.

27 Wasserstein, Why did Arabic succeed 187.

28 Fowden, Qușayr Amra 266
} 
no need was felt for a parallel Arabic version of the Greek inscription. ${ }^{29}$ The use of Greek creates continuity with previous Byzantine and Roman dedications and public inscriptions, and continues the epigraphic tradition, linking the new regime to the old ones and evoking imperial power. In contrast, the Arabic inscriptions found in the vicinity are private inscriptions, prayers for forgiveness or commemoration, rather than statements of authority. ${ }^{30}$ Similarly, Syriac inscriptions in Palestine, dating to the fourth and fifth century, are found in private houses. This is significant in reinforcing the understanding that the line of demarcation between the languages is not simply about the division between written and spoken languages.

\section{Conclusion}

In the 2000 U.s. census, over 6.7 million Americans checked more than one box in describing their race and ethnicity. To them, a constricting, exclusive understanding of ethnicity is nonsensical and out of touch with their lives. If we were to confront the people of Nessana with a similar question - and if they understood what we meant by ethnicity, which is another question entirely - the results of multiple definitions would surely have been even higher than in the U.s. This paper argues that the Nessana papyri suggest that language use was determined by context and situation; and that languages were used to make claims of power, rather than ethnicity. In other words, the same man might well use Greek in one context and Arabic in another, depending on the message he wished to convey to his interlocutors and on the content of the communication. Linguistic usage alone cannot therefore be used to determine the ethnic, religious, or cultural identity of the speaker/writer, but only that facet which is being emphasised in a given situation.

If we return to the example with which we began-our discouraged and frustrated letter writer-we can now see that this neglected papyrus affords us a glimpse into people's motives for insisting on Greek. This is a man who is incapable of composing a simple letter in Greek; and yet there is one line he considers important enough to practice over and over again, and that is the standard formula beginning a formal letter, an appeal to authority or any other kind of legal document. Greek writing is important to master not just so that one may write formal letters (since this individual has shown that he

29 SEG 30 no. 1687; SEG 32 no 1501.

30 Sharon, Five Arabic inscriptions. 
is incapable of doing so); the ability to string together Greek letters takes on an almost magical meaning, creating the illusion of participation in the life of influence. The standard epistolary formula declaring the writer's literacy, with

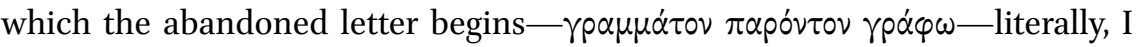
write to you since I possess letters - takes on an added poignancy. In this case, the literal interpretation is applicable, but the meaning of the phrase- $-\mathrm{a}$ declaration of literacy and competence as a scribe-is not.

Both before and after the Muslim conquest, Greek was used for the overtones it carried as much as for its familiarity as a spoken language. Instead of explaining the idiosyncrasies of Greek in late Roman Palestine and in Umayyad Filasțin using two different models, one spectrum emerges. Averil Cameron has already argued that the change from Greek to Arabic was neither as sudden nor as complete as has been thought. The Nessana papyri uphold this insight, and suggest that the nature of this change has been wrongly understood: this is not a story of a shift from one spoken language to another, but of the change in the connotations each language carried. Until Arabic was well established enough to connote power and formality by itself, the Muslim administration continued to use Greek as it had been used before them: not to signify cultural identity, but to signal status and intentions. ${ }^{31}$ In trying to understand the complexities of this society, imposing an anachronistic linguistic dichotomy can only be a hindrance.

\section{Bibliography}

Amory, P., People and identity in ostrogothic Italy, 489-554, Cambridge 1997, repr. Cambridge 2003.

Banniard, M., Viva Voce. Communication écrite et communication orale du IVe au IXe siècle en Occident latin, Paris 1992.

Boud'hors, A., Du copte dans les archives d'Apollôs, in J.-L. Fournet and C. Magdelaine (eds.), Les archives de Dioscore d'Aphrodité cent ans après leur découverte. Histoire et culture dans l'Égypte byzantine, Paris 2008, 67-76.

Bowersock, G.W., Hellenism in late antiquity, Ann Arbor 1990.

Cameron, A., The Mediterranean world in late antiquity, New York and London 1993.

31 See also the Greek inscription, mentioning also Arab-named visitors to the Egyptian monastery of Bawit (Fournet, Conversion religieuse). For the continued use of Greek in Arab Egypt, see also Morelli's introductions to $C P R$ XXII and $C P R$ XXX as well as Sijpesteijn, Arabic-Greek archives. 
Casson, L. and E.L. Hettich, Excavations at Nessana, volume 2: Literary papyri, Princeton $195^{0 .}$

Daniel, R.W., P. Petra inv. 10 and its Arabic, in I. Andorlini et al. (eds.), Atti del XXII congresso internazionale di papirologia, Florence 2001, 331-341.

Donner, F., The early Islamic conquests, Princeton 1981.

Fournet, J.-L., Archive ou archives de Dioscore? Les dernières années des "archives de Dioscore", in J.-L. Fournet and C. Magdelaine (eds.), Les archives de Dioscore d'Aphrodité cent ans après leur découverte. Histoire et culture dans l'Égypte byzantine, Paris 2008, 17-30.

. The multilingual environment of late antique Egypt: Greek, Latin, and Persian documentation, in R.S. Bagnall (ed.), The Oxford handbook of papyrology, Oxford 2009, 418-451.

- Conversion religieuse dans un graffito de Baouit? Revision de $S B$ III 6042, in A. Boud'hors, J. Clackson, C. Louis et al. (eds.), Monastic estates in late antique and early Islamic Egypt. Ostraca, papyri, and essays in memory of Sarah Clackson (P.Clackson), Cincinnati 2009, 141-147.

Fowden, G., Qușayr Amra: Art and the Umayyad elite in late antique Syria, Berkeley 2004.

Geiger, J., How much Latin in Greek Palestine?, in H. Rosen (ed.), Aspects of Latin: Papers from the seventh international colloquium on Latin linguistics, Innsbruck 1996, 39-57.

Griffith, S., From Aramaic to Arabic: The languages of the monasteries of Palestine in the Byzantine and early Islamic periods, in Dumbarton Oaks Papers 51 (1997), 11-31. Hall, J.M., Ethnic identity in Greek antiquity, Cambridge 1997.

Hoyland, R., Language and identity: The twin histories of Arabic and Aramaic, in Scripta classica Israelica 23 (2004), 183-199.

Jones, S., The archaeology of ethnicity: Constructing identities in the past and present, London and New York 1997.

Kraemer, C.J., Excavation at Nessana, volume 3: Non-literary papyri, Princeton 1958.

Mango, C., Greek culture in Palestine after the Arab conquest, in G. Cavallo, G.D. Gregorio and M. Maniaci (eds.), Scritture, libri e testi nelle agree provinciali di bisanzio: atti del seminario de Erice, Spoleto 1991, 149-16o.

Millar, F., Ethnic identity in the Roman Near East A.D. 325-450: Language, religion, and culture, in Mediterranean archaeology 11 (1998), 159-176.

Papaconstantinou, A., Dioscore et la question du bilinguisme dans l'Egypte du vie siècle, in J.-L. Fournet and C. Magdelaine (eds.), Les archives de Dioscore d'Aphrodité cent ans après leur découverte. Histoire et culture dans l'Égypte byzantine, Paris 2008, 77-88.

Richter, T.S., Language choice in the Qurra papyri, in A. Papaconstantinou (ed.), The multilingual experience: Egypt from the Ptolemies to the 'Abbāsids, Oxford 2010, 189219 . 
Sharon, M., Five Arabic inscriptions from Rehoboth and Sinai, in Israel exploration journal 43 (1993), 50-59.

Shboul, A. and A. Walmsley, Identity and self-image in Syria-Palestine in the transition from Byzantine to early Islamic rule: Arab Christians and Muslims, in Mediterranean archaeology 11 (1998), 255-287.

Sijpesteijn, P.M., The Arab conquest of Egypt and the beginning of Muslim rule, in R.S. Bagnall (ed.), Egypt in the Byzantine world 300-70o, Cambridge 2007, 437-459. Arabic-Greek archives, in A. Papaconstantinou (ed.), The multilingual experience in Egypt, from the Ptolemies to the 'Abbāsids, Burlington 2010, 105-126.

Vieros, M., Bilingual notaries in Hellenistic Egypt: A study of Greek as a second language, Brussels 2012.

Wasserstein, D., Why did Arabic succeed where Greek failed? Language change in the Near East after Muhammad, in Scripta classica Israelica 22 (2003), 257-272.

Wipszycka, E., Le nationalisme a-t-il existé dans l'Égypte byzantine?, in Journal of juristic papyrology 22 (1992), 83-128. 